\title{
Clinical Features of Respiratory Syncytial Virus Infection in Neonates: A Single Center Study
}

\author{
Sung Hui Chang, Gwang Cheon Jang*, and Shin Won Yoon* \\ Department of Pediatrics, Severance Children's Hospital, Yonsei University College of Medicine, Seoul, Korea \\ Department of Pediatrics*, National Health Insurance Service Ilsan Hospital, Goyang, Korea
}

\section{ABSTRACT}

Purpose: The aim of this study was to investigate the clinical characteristics of Respiratory syncytial virus (RSV) infection during the neonatal period to provide information that is useful in clinical practice and suggest extension of the palivizumab administration.

Methods: Neonates admitted to the National Health Insurance Service Ilsan Hospital neonatal intensive care unit due to respiratory symptoms and for whom multiplex reverse transcription-polymerase chain reaction and multiplex real time-polymerase chain reaction tests were performed between October 2011 and May 2016 were included in this study. Medical records were retrospectively reviewed, and data was collected for 156 neonates.

Results: Among the 156 neonates, RSV was detected in 114 (73.1\%), non-RSV in 25 (16\%), and no virus in 17 (10.9\%). The majority were full term infants (92.4\%) and peak incidence of RSV infection was in January. Post-natal care center infection was more common in the RSV group ( $46.6 \%)$ than that in the other virus groups $(24 \%, P=$ 0.0243). Clinical symptoms were severe in the RSV group in contrast to that in the non-RSV or others groups. The RSV group frequently needed oxygen therapy ( $P=$ $0.0001)$ and the duration of hospital stays were longer $(P=0.0001)$.

Conclusion: RSV is a significant cause of respiratory infection in neonates and the severity is higher in contrast to that with other viral causes of infection. Infants in post-natal care centers have a high-risk of developing RSV infections; therefore, palivizumab administration may be considered in this group to prevent hospitalization and reduce the duration of hospital stay.

Key Words: Respiratory syncytial viruses, Newborn, Palivizumab, Post-natal care center

\section{서론}

호흡기세포융합바이러스(respiratory syncytial virus, RSV)는 영아의 50\%-80\%에서 생후 1년 이내 감염된다는 보고가 있을 정도로 흔한 호흡기 감염원으로, 감염 연령이 어릴수록 증상이 심
Received: 19 June 2018

Revised: 13 August 2018

Accepted: 12 September 2018

Correspondence to: Shin Won Yoon

Department of Pediatrics, National

Health Insurance Service Ilsan Hospital, 100 Ilsan-ro, Ilsandong-gu, Goyang 10444, Korea

Tel: +82-31-900-0259

Fax: +82-31-900-0343

E-mail: swyoon@nhimc.or.kr

Copyright(c)

By Korean Society of Neonatology.

All right reserved.

This is an Open-Access article distributed under the terms of the Creative Commons Attribution Non-Commercial License (http://creativecommons.org/licenses/ by-nc/4.0), which permits unrestricted non-commercial use, distribution, and reproduction in any medium, provided the original work is properly cited. 
하여 입원 치료가 필요한 경우가 증가한다 ${ }^{1,2)}$. 면역력이 감소되어 있 는 신생아, 특히 폐 성숙이 미숙한 미숙아에서는 RSV 감염으로 인한 유병률과 사망률이 증가하는 것으로 알려져 있다, ${ }^{3,4}$. 현재 RSV 감염 의 예방요법으로 RSV 단클론항체인 palivizumab을 사용 중이며,(6), 보험 기준이 까다로워 미숙아, 기관지 폐이형성증, 선천성 심장질환 이 있는 고위험 환아들에게 제한적으로 사용되고 있다. 현재 우리나 라에서는 RSV 유행 기간 동안 생후 6개월 이하이면서 재태 기간이 32 주 미만인 미숙아거나, 재태 기간이 36주 미만이면서 한 명 이상 의 손위 형제 또는 손위 자매가 있는 경우에 한해 보험이 적용된다.

지금까지 RSV 감염에 관하여 미숙아, 저체중 출생아, 기관지 폐이 형성증 등의 위험인자를 가진 환자에 대한 연구들이 대부분이었으 며, 기저질환이 없는 만삭 신생아의 RSV 감염에 대한 임상 연구는 상 대적으로 부족하다. 그러나 만삭아에서 심각한 RSV 감염으로 인하 여 신생아집중치료실에서 치료받는 경우가 적지 않곡 $\mathrm{RSV}$ 감염으 로 인한 하부 호흡기질환으로 입원한 미숙아 및 만삭신생아에 관한 연구에서 미숙아와 이전에 건강했던 만삭 신생아 사이에 RSV 감염 으로 인한 입원율의 차이가 없었음을 확인한 연구 ${ }^{8}$ 가 있었다. 이에 본 연구에서는 호흡기 감염으로 신생아집중치료실에 입원이 필요했 던 신생아를 대상으로 RSV 감염의 역학적 특성과 임상적 특징에 대 하여 분석해보고자 하였다. 또한 RSV 감염의 위험인자를 확인하여 palivizumab의 예방요법 투여 대상군을 재검토할 수 있는 근거를 얻 고자하였다.

\section{대상 및 방법}

\section{1. 연구 대상}

2011년 9월 1일부터 2016년 5월 31일까지 호흡기증상으로 국민 건강보험 일산병원 신생아집중치료실에 입원하여 다중 역전사중 합효소연쇄반응 (multiplex reverse transcription polymerase chain reaction, multiplex RT PCR) 및 다중 실시간중합효소연쇄반응 (multiplex real time polymerase chain reaction, multiplex real time $\mathrm{PCR})$ 으로 바이러스 검사를 시행한 환아 156 명을 대상으로 입원 기 록을 후향적으로 검토하였다. 연구 기간은 5년간 RSV가 검출되었던 시기를 기준으로 하여 2011년 9월부터 2012년 8월까지를 Season 1, 2012년 9월부터 2013년 8월까지를 Season 2, 2013년 9월부터 2014 년 8월까지를 Season 3, 2014년 9월부터 2015년 8월까지를 Season 4, 2015년 9월부터 2016년 5월까지를 Season 5로 총 다섯 시즌으로 나누어 RSV 아형을 시즌별로 분석하였다. 입원 대상 환아는 생후 30 일 이하의 신생아였고, 생후 30 일 이후라도 미숙아 출생으로 입원 시 교정연령 44 주 이내 또는 체중이 $5 \mathrm{~kg}$ 미만인 경우는 신생아집중 치료실로 입원하게 되어 대상자에 포함되었다. 선천성 심질환 등의 선천적 이상이 있는 경우와 혈액이나 호흡기 분비물에서 균이 동정
된 세균성 감염 환자는 대상에서 제외하였다.

\section{2. 방법}

관찰 항목으로 임신 주수, 성별, 출생방식, 모유수유, 입원 시 나 이, 입원 시 체중, 산후조리원 이용, 형제자매 유무를 조사하였고 감 염 증상으로는 기침, 발열, 흉곽함몰, 빈호흡, 수유 곤란, 무호흡, 흡 기수포음, 산소포화도의 항목으로 나누어 확인하였다. 검사 및 치료 에 대하여 말초혈액 백혈구 수, C-반응단백, 흥부방사선검사, 산소 치료 유무, 기계환기사용 유무, 입원 기간을 분석하였다. 발열은 겨 드랑이 체온 기준 $38^{\circ} \mathrm{C}$ 이상으로 정의하였고, 빈호흡은 호흡수 분 당 60 회 이상이 수유 시간과 상관없이 4 시간 이상으로 지속될 때로 정의하였다. 수유 곤란은 수유량이 평소의 절반 이하로 줄었을 때 나 호흡곤란으로 인해 수유가 진행되지 않을 때로 정의하였으며, 무 호흡은 20 초 이상 호흡이 중지된 경우 또는 시간에 관계없이 서맥이 나 청색증이 동반되는 경우로 정의하였다. C-반응단백의 증가는 $>1$ $\mathrm{mg} / \mathrm{dL}$ 를 기준으로 하였다. 폐렴과 기관지염은 진찰소견과 흥부방 사선검사에서 이상이 있는 경우로 정의하였고, 흉부방사선검사는 소아 영상의학과 전문의 판독과 신생아분과 전문의에 의하여 정상 소견과 이상 있는 경우로 분류하였으며, 폐렴은 폐실질에 음영 증가 가 있거나 무기폐가 보일 때로 정의하였다. 기관지염은 폐의 과팽창 소견과 기관지 주위의 음영 증가가 있는 경우로 정의하였다. 기계적 환기는 산소를 투여하였음에도 흥곽함몰이나 비익확장, 빈호흡 등 호흡기 이상 징후가 지속되며 스스로 환기를 유지할 수 없거나 반복 되는 무호흡 또는 과탄산혈증의 경우 기관삽관을 통해 시행하였다.

\section{3. 바이러스 검사 방법}

호흡기바이러스 검사 방법으로는 면봉을 이용하여 코를 통해 비 인두 분비물을 채취한 후 검체를 비인두 도말 용기에 담아 시행하였 다. 바이러스의 검출은 검체에서 RNA를 추출한 multiplex RT PCR 또는 multiplex real time PCR을 이용하여 시행하였다.

검사 항목은 연도에 따라 차이가 있었으며, 2011년 9월부터 2015 년 10월까지 Seeplex (Seegene Biotechnology Inc., Seoul, Korea) 제품을 사용하여 RSV A, B, influenza virus A, B, corona virus 229E/NL63, OC43/HKU1, adenovirus, human metapneumovirus, parainfluenza virus 1,2,3, human rhinovirus 총 12종의 호흡기 바 이러스에 대해 검사하였다. 이후 2015년 11월부터 2016년 5월까지 AdvanSure (LG Life Sciences, Seoul, Korea) 제품을 사용하여 RSV A, B, influenza virus A, B, corona virus 229E, NL63, OC43, adenovirus, human metapneumovirus, parainfluenza virus 1, 2, 3, human rhinovirus, human bocavirus가 포함된 14종 검사를 시행하였다.

Multiplex RT PCR 검사를 위하여 사용한 Seeplex 제품으로는 조 성을 모형 $3.0 \mu \mathrm{L}, 5 \times \mathrm{RV} 2$ primer $4.0 \mu \mathrm{L}, 2 \times$ multiplex Master Mix 10 $\mu \mathrm{L}$ 의 총 $20 \mu \mathrm{L}$ 용량으로 하여 반응시켰다. 반응조건은 $94^{\circ} \mathrm{C}$ 에서 15 
분 반응 후 $94^{\circ} \mathrm{C} 30$ 초, $60^{\circ} \mathrm{C} 1.5$ 분, $72^{\circ} \mathrm{C} 1.5$ 분의 반응을 1 회로 하여 40 회 반복하였고, 최종 연장반응을 $72^{\circ} \mathrm{C}$ 에서 10 분간 시행하였다. 이 용액 $5 \mu \mathrm{L}$ 을 $2 \%$ 순수 우무겔(agarous gel)로 전기영동하여 ethidium bromide로 염색 후 자외선램프를 쪼여 결과를 판독하였다.

Multiplex real time PCR은 추출된 DNA를 $5 \mu \mathrm{L}$ 의 프라이머 prove mix와 $10 \mu \mathrm{L}$ 의 1단계 RT PCR premix를 함유하는 튜브에 첨가하고 역전사 단계를 위해 이 혼합물을 $50^{\circ} \mathrm{C}$ 에서 10 분간 배양하여, $95^{\circ} \mathrm{C}$ 에서 30 초간 변성시킨 후 $95^{\circ} \mathrm{C}$ 에서 15 초, $53^{\circ} \mathrm{C} 30$ 초, $60^{\circ} \mathrm{C}$ 30초를 1 회로 하여 10 회 반복하였다. 이어서, 형광 신호를 검출하기 위해 $95^{\circ} \mathrm{C}$ 에서 15 초, $53^{\circ} \mathrm{C}$ 에서 30 초, $60^{\circ} \mathrm{C}$ 에서 30 초를 1 회로 하여, 30 회의 추가 PCR 사이클을 반복하였다. 이 분석은 PCR 반응과 함께 ribonuclease P를 사용하여 추출된 RNA로 역전사 반응을 동시에 수 행하였다.

\section{4. 통계}

자료 분석을 위하여 SPSS window version 18.0 (SPSS Inc., Chicago, IL, USA)을 사용하였고, 환자의 특성, 임상 양상 및 검사 결 과의 비교는 변수의 특성에 따라 연속형 변수는 비모수적 방법인 Kruskal-Wallis test와 Mann-Whitney test를 사용하였고, 범주형 변수 는 chi-square test와 Fisher's exact test를 사용하여 분석하였다. 변수 의 표기는 연속형은 중앙값(사분위범위)으로, 범주형은 number (\%) 으로 표시하였다. $P$ 값이 0.05 미만인 경우 통계학적 유의성이 있는 것으로 판단하였으며 사후분석 시 다중비교에 대한 $P$ 값 보정을 위 해 Bonferroni correction을 사용하였다.

\section{결과}

\section{1. 호흡기바이러스 검출 빈도}

연구에 포함되었던 환아는 총 156 명이었으며 이중 RSV 감염은 114 명(73.1\%)으로 대부분을 차지하였다(Table 1). RSV 감염 114예 중에는 RSV A만 감염된 경우 79예(50.6\%), RSV B만 감염된 경우는 24 예(15.4\%), 다른 바이러스와 동반 감염된 경우가 11 예(7.1\%) 포함 되어 있었다. RSV A와 다른 바이러스와 중복감염이 있었던 경우는 7 예가 있었고, RSV B와 다른 바이러스와 중복감염이 있었던 경우는 4 예가 있었다. 그 중 RSV A와 human rhinovirus와의 중복감염은 7예, RSV B와 human rhinovirus의 중복감염은 2예, RSV B와 influenza A 의 중복감염이 1 예, RSV B와 parainfluenza 3 의 중복감염이 1 예 있었 다.

Non-RSV군은 25예(16.0\%)가 있었으며 human rhinovirus가 7예 (10.9\%), parainfluenza 3이 4예(2.6\%), human metapneumovirus가 2예(1.3\%)가 있었고, human rhinovirus와 human metapneumovirus 의 중복감염이 1 예 $(0.6 \%)$ 있었다. PCR 검사 음성으로 확인된 Others
군은 17예(10.9\%) 였다(Table 1).

\section{2. 연도별 및 월별 분포}

Season 1까지는 RSV A 감염만 있는 것을 확인할 수 있었다. Season 2에는 RSV A (88.6\%)가 대부분이나 RSV B (11.4\%)도 나타났 으며, Season 3에서는 RSV B 감염만 있었다. Season 4에서는 RSV A (95.0\%)가 우세하였고, Season 5 시기에는 RSV B (92.3\%)가 우세하 여 해마다 유행하는 아형에 차이가 있음을 확인할 수 있었다(Figure $1)$.

총 5년간의 월별 바이러스 분포를 분석하여 보았을 때 RSV는 주로 10 월부터 증가하기 시작하여 3월까지 빈도가 높았으며, 6월 이후 여 름에는 검출되지 않았다. 반면 다른 바이러스에서는 연중 변동을 확 인할 수 없었다(Figure 1).

\section{RSV 감염의 인구학적 분포}

바이러스 검사상 RSV 양성으로 확인된 114 명 중 다른 바이러스와 중복 감염된 11 명을 제외한 RSV군 103 명, RSV 이외에 다른 바이러 스에 감염된 non-RSV군 25 명, 바이러스가 검출되지 않아 호흡기 감 염의 원인이 확인되지 않은 Others군 17 명을 세 군으로 나누어 비교 분석하였다(Table 2).

RSV군 환아의 재태 연령 중앙값은 39.0주(사분위범위, 38.240.0) 였으며, 미숙아는 RSV군 7명, non-RSV군 3명, Others군 1명 으로 미숙아 재태 연령 중앙값은 각각 RSV군 36.2주(사분위범위, 34.3-36.5), non-RSV군 36.0주(사분위범위, 30.1-36.1), Others

Table 1. The Frequency of Viruses Detected in Patients Admitted to the Neonatal Intensive Care Unit: RSV Group, Non-RSV Group, and Others Group

\begin{tabular}{lc}
\hline Viral agents & No. of patients $(\%)$ \\
\hline RSV A/B & $114(73.1)$ \\
RSV A & $79(50.6)$ \\
RSV B & $24(15.4)$ \\
Coinfection with other virus* & $11(7.1)$ \\
Non-RSV & $25(16.0)$ \\
hRV A/B & $17(10.9)$ \\
PIV3 & $4(2.6)$ \\
HMPV & $2(1.3)$ \\
CoronaV 229E/NL63 & $1(0.6)$ \\
hRV+HMPV & $1(0.6)$ \\
Others & $17(10.9)$ \\
Total & $156(100)$
\end{tabular}

*Coinfection with other virus: RSV A+hRV (7 cases), RSV B+hRV (2 cases), RSV B+influenza A (1 case), RSV B+PIV3 (1 case).

Abbreviations: RSV, respiratory syncytial virus; $h R V$, human rhinovirus; PIV3, parainfluenza virus 3; HMPV, human metapneumovirus; CoronaV, corona virus. 


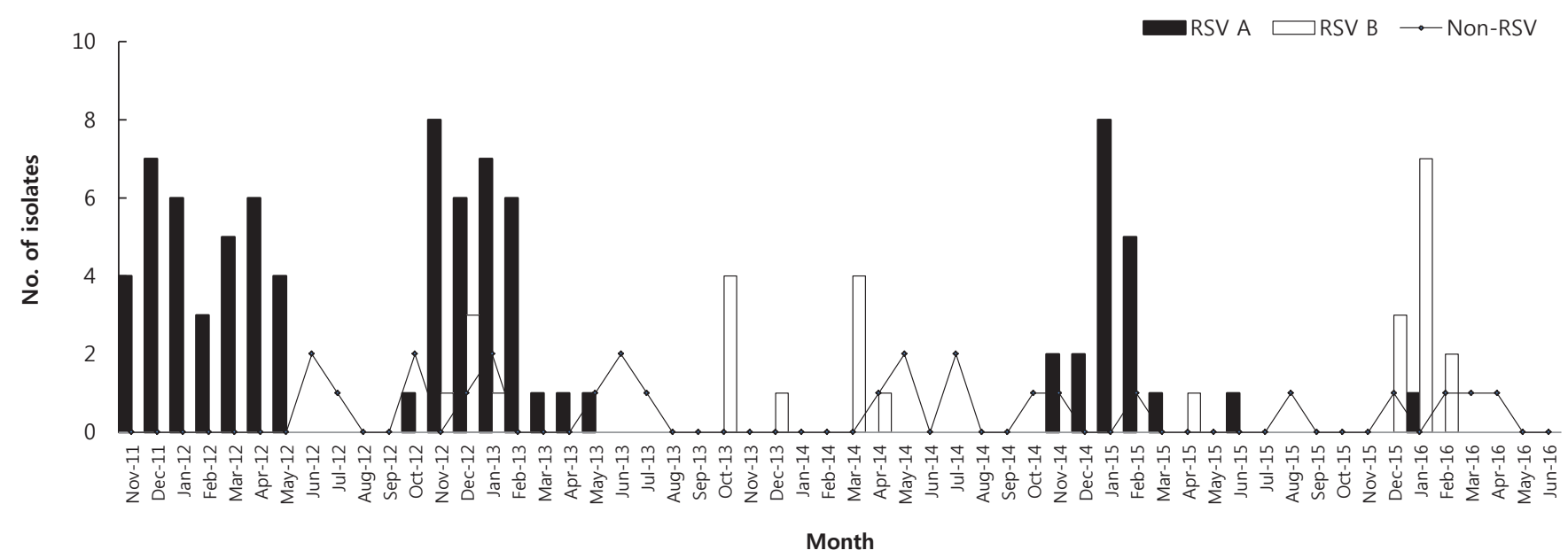

Figure 1. Seasonal and monthly distribution of respiratory syncytial virus (RSV) A, RSV B, and non-RSV viruses for a 5-year period from 2011 to 2016. Season 1: September 2011 to August 2012; Season 2: September 2012 to August 2013; Season 3: September 2013 to August 2014; Season 4: September 2014 to August 2015; and Season 5: September 2015 to May 2016.

Table 2. Demographic Comparison: RSV Group, Non-RSV Group, and Others Group

\begin{tabular}{|c|c|c|c|c|}
\hline Variable & $\operatorname{RSV}(n=103)$ & Non-RSV $(n=25)$ & Others $(n=17)$ & $P$-value \\
\hline Gestational age (wk) & $39(38.2-40.0)$ & $39(38.1-40.0)$ & $38.1(38.0-39.5)$ & 0.2410 \\
\hline Prematurity (<37 wk) & $7(6.8)$ & $3(12.0)$ & $1(5.9)$ & 0.6149 \\
\hline Age of preterm infant (wk) & $36.2(34.3-36.5)$ & $36.0(30.1-36.1)$ & $36.4(36.4-36.4)$ & 0.4012 \\
\hline Birth weight (g) & $3,340(2,980-3,560)$ & $3,300(3,060-3,500)$ & $3,220(3,000-3,360)$ & 0.5702 \\
\hline Male sex & $45(43.6)$ & $15(60.0)$ & $9(52.9)$ & 0.3062 \\
\hline $\mathrm{C} / \mathrm{sec}$ & $31(30.1)$ & $10(40.0)$ & $4(23.5)$ & 0.4895 \\
\hline Breast milk feeding & $94(91.3)$ & $21(88.0)$ & $16(94.1)$ & 0.7569 \\
\hline Age at admission $(\mathrm{d})^{\dagger}$ & $20(16-26)$ & $24(19-28)$ & $19(14-23)$ & $0.0232^{*}$ \\
\hline Weight at admission $(\mathrm{g})^{\dagger}$ & $3,800(3,380-4,220)$ & $4,050(3,780-4,530)$ & $3,510(3,440-3,960)$ & $0.0132^{*}$ \\
\hline Post-natal care center ${ }^{\S}$ & $48(46.6)$ & $6(24.0)$ & $7(43.8)$ & $0.0288^{*}$ \\
\hline One or more siblings" & $45(43.7)$ & $19(76.0)$ & $7(41.2)$ & $0.0118^{*}$ \\
\hline
\end{tabular}

Values are expressed as median (interquartile range) or number (\%). Post hoc P-value (RSV vs. non-RSV, RSV vs. others, non-RSV vs. others respectively).

${ }^{*} P<0.05$, statistically significant; ${ }^{\dagger}$ Age at admission: $0.0432,>0.9999,0.0690$; ${ }^{*}$ Weight at admission: $0.0522,0.7347,0.0105 ;{ }^{\S}$ Post-natal care center: 0.0243, >0.9999, 0.5547; " One or more siblings: 0.0114, >0.9999, 0.0675 .

Abbreviations: RSV, respiratory syncytial virus; C/sec, caesarean section.

군 36.4주(사분위범위, 36.4-36.4)로 후기 미숙아에 해당하였다.

세 군 간의 재태 연령의 차이는 보이지 않았다 $(P=0.2410)$. 입원 당 시 나이의 중앙값은 RSV군이 생후 20 일(사분위범위, 16-26일)였고 non-RSV군 24일(사분위범위, 19-28), Others군 19일(사분위범위, 14-23)과 비교하였을 때 의미 있는 차이를 보였다(RSV $P=0.0232$ vs. non-RSV $P<0.0432)$. 산후 조리원에서 증상이 생겨 내원한 경우는 $\mathrm{RSV}$ 군에서 48명(46.6\%)으로 non-RSV군 6명(24.0\%)보다 의미 있게 높았다(RSV $P=0.0288$ vs, non-RSV $P<0.0243$ ). 한 명 이상의 형제 혹 은 자매가 있는 경우는 non-RSV군에서 19명 $(76.0 \%)$ 으로 유의하게 높았다(RSV $P=0.0118$ vs. non-RSV $P<0.0114$ ). 출생 체중, 성별과 분 만 방식에서는 RSV군과 다른 군 간에 유의한 차이가 없었으며, 모유
수유 여부도 각 군 간에서 유의한 차이가 없었다.

\section{RSV 감염의 임상 양상과 차이}

RSV군에서 가장 많이 나타나는 증상은 기침이었으며(99.0\%), 흡 기수포음(64.1\%), 흥곽함몰 $(55.3 \%)$, 산소포화도 감소(35.9\%), 빈 호흡(35.0\%), 수유량 감소(28.2\%), 발열(18.5\%), 무호흡(1.9\%) 순 으로 증상 발현이 있었다(Table 3 ). $38^{\circ} \mathrm{C}$ 이상의 발열은 non-RSV 군에서 $60.0 \%$ 로 RSV군 $18.5 \%$ 보다 높았다(RSV $P \leq 0.0001$ vs. non$\operatorname{RSV} P<0.0001$ ). 흥곽함몰은 RSV군에서 $55.3 \%$ 로 non-RSV군 $20.0 \%$ 와 비교하였을 때 유의하게 높은 빈도를 보였다(RSV $P=0.0021$ vs. non-RSV $P<0.0045)$. 흡기수포음도 RSV군에서 64.1\%로 non-RSV군 
Table 3. Clinical Characteristics: RSV Group, Non-RSV Group, and Others Group

\begin{tabular}{|c|c|c|c|c|}
\hline Characteristic & $\operatorname{RSV}(n=103)$ & Non-RSV $(n=25)$ & Others $(n=17)$ & $P$-value \\
\hline $\operatorname{Cough}^{\dagger}$ & $102(99.0)$ & $23(92.0)$ & $14(82.4)$ & $0.0044^{*}$ \\
\hline Fever $>38^{\circ} \mathrm{C}^{\ddagger}$ & $19(18.5)$ & $15(60.0)$ & $7(41.2)$ & $<0.0001^{*}$ \\
\hline Chest retraction $^{\S}$ & $57(55.3)$ & $5(20.0)$ & $5(29.4)$ & $0.0021^{*}$ \\
\hline Tachypnea & $36(35.0)$ & $4(16.0)$ & $3(17.7)$ & 0.0910 \\
\hline Poor feeding & $29(28.2)$ & $2(8.0)$ & $2(11.8)$ & 0.0505 \\
\hline Apnea & $2(1.9)$ & 0 & $1(5.9)$ & $>0.9999$ \\
\hline Rales" & $66(64.1)$ & $4(16.0)$ & $1(5.9)$ & $<0.0001^{*}$ \\
\hline $\mathrm{O}_{2}$ sat $\leq 94^{\mathrm{c}}$ & $37(35.9)$ & $2(8.0)$ & $5(29.4)$ & $0.0244^{*}$ \\
\hline C-reactive protein $>1 \mathrm{mg} / \mathrm{dL}^{* *}$ & $11(10.7)$ & $3(12.0)$ & $6(35.3)$ & $0.0370^{*}$ \\
\hline WBC count & $10,630(8,420-12,440)$ & $11,400(9,520-12,490)$ & $11,900(7,660-14,830)$ & 0.6673 \\
\hline Abnormal X-ray $^{\dagger \dagger}$ & $67(65.1)$ & $4(16.0)$ & $8(47.1)$ & $0.0001^{*}$ \\
\hline 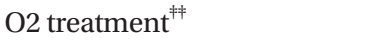 & $63(61.2)$ & $4(16.0)$ & $6(35.3)$ & $0.0001^{*}$ \\
\hline Ventilator care & $3(2.9)$ & 0 & 0 & $>0.9999$ \\
\hline Hospital days $(\mathrm{d})^{\S \S}$ & $6(5-8)$ & $4(4-5)$ & $4(4-6)$ & $<0.0001^{*}$ \\
\hline
\end{tabular}

Values are expressed as number (\%) or median (interquartile range). Post hoc P-value (RSV vs. non-RSV, RSV vs. others, non-RSV vs. others respectively).

${ }^{*} P<0.05$, statistically significant; ${ }^{\dagger}$ Cough: $0.2919,0.0264,>0.9999 ;{ }^{\dagger}$ Fever $>38^{\circ} \mathrm{C}:<0.0001,0.1599,0.6918 ;{ }^{\S}$ Chest retraction: $0.0045,0.1986,0.9999 ; "$ Rale: $<0.0001,0.0001,0.9999 ;{ }^{\top} \mathrm{O}_{2}$ sat $\leq 94: 0.0195,0.9999,0.2964 ;{ }^{* *} \mathrm{C}$-reactive protein $>1 \mathrm{mg} / \mathrm{dL}:<0.0001,0.0474,0.3726 ;{ }^{\dagger \dagger} \mathrm{Abnormal} \mathrm{X-ray:}<0.0001,0.4674$, $0.1221 ;{ }^{* \dagger} \mathrm{O}_{2}$ treatment: $<0.0001,0.1368,0.8040 ;{ }^{\circledR \varsigma}$ Hospital days: $<0.0001,0.0135,0.9999$.

Abbreviations: RSV, respiratory syncytial virus; WBC, white blood cell.

$16.0 \%$ 에 비하여 높은 비율로 확인되어(RSV $P<0.0001$ vs. non-RSV $P<0.0001), \mathrm{RSV}$ 군에서 심한 호흡기 증상을 보임을 확인할 수 있었 다. 산소포화도가 $94 \%$ 이하로 감소된 경우는 RSV군에서 $35.9 \%$ 로 non-RSV군 8.0\%에 비해 유의하게 높았다(RSV P=0.0244 Vs, non$\operatorname{RSV} P<0.0195)$. 흥부방사선검사상 이상 소견을 보인 경우는 RSV군 에서 의미 있게 많았다(RSV $P=0.0001$ vs. non-RSV $P<0.0001)$. 산 소 치료가 필요한 경우도 RSV군에서 $61.2 \%$ 로 유의하게 높았고(RSV $P=0.0001$ vs. non-RSV $P<0.0001)$, 고식적 기계환기가 필요한 경우 도 RSV군(2.9\%)에서만 있었다. 재원기간의 중앙값은 6일(사분위범 위, 5-8)로 non-RSV군 4일(사분위범위, 4-5), Others군 중앙값 4일 (사분위범위, 4-6)과 비교하였을 때 다른 군에 비하여 평균 2일 정 도 지연되어 있음을 확인할 수 있었다(RSV $P \leq 0.0001 \mathrm{vs.} \mathrm{non-RSV}$ $P<0.0001)$. C-반응단백 증가는 Others군에서 가장 높은 빈도를 나타 내었다 $(P=0.0370)$, 수유량이 감소한 환자의 수와 말초혈액 백혈구 수치는 각 군 간의 통계적인 차이는 없었다.

\section{RSV 아형간 임상 양상 비교}

RSV type A 79예와 type B 24예 두 그룹 간의 임상 양상을 비교해 보았을 때, 두 군 간의 차이는 없었다(Table 4).
Table 4. Clinical Characteristics of Respiratory Syncytial Virus A and Respiratory Syncytial Virus B

\begin{tabular}{lccr}
\hline Characteristic & $\begin{array}{c}\text { RSV A only } \\
(\mathrm{n}=79)\end{array}$ & $\begin{array}{c}\text { RSV B only } \\
(\mathrm{n}=24)\end{array}$ & $\begin{array}{c}P \text { - } \\
\text { value }\end{array}$ \\
\hline Cough & $78(98.7)$ & $24(100.0)$ & $>0.999$ \\
Fever $>38^{\circ} \mathrm{C}$ & $16(20.3)$ & $3(12.5)$ & 0.552 \\
Chest retraction & $44(55.7)$ & $13(54.2)$ & 0.895 \\
Tachypnea & $30(38.0)$ & $6(25.0)$ & 0.243 \\
Poor feeding & $22(27.8)$ & $7(29.2)$ & 0.901 \\
Rales & $50(63.3)$ & $16(66.7)$ & 0.763 \\
O2 sat $\leq 94$ & $51(64.6)$ & $15(62.5)$ & 0.854 \\
WBC count & $10,830(8,420-13,400)$ & $10,590(8,215-11,925)$ & 0.422 \\
C-reactive protein & $9(11.4)$ & $2(8.3)$ & $>0.999$ \\
$\geq 1$ mg/dL & & & \\
Abnormal X-ray & $50(63.3)$ & $17(70.8)$ & 0.502 \\
O2 treatment & $47(59.4)$ & $16(66.7)$ & 0.528 \\
Ventilator care & $2(2.5)$ & $1(4.2)$ & 0.553 \\
Hospital days (d) & $6(5-9)$ & $6.5(5-7)$ & 0.631 \\
\hline
\end{tabular}

Values are expressed as number (\%) or median (interquartile range). Abbreviations: RSV, respiratory syncytial virus; WBC, white blood cell.

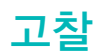

본 연구에서는 호흡기 증상으로 신생아집중치료실에 입 원 치료 
가 필요하였던 신생아를 대상으로 신생아기의 RSV 감염의 역학적 특징과 임상적 특징에 관하여 분석해보고자 하였다. 이번 연구를 통 하여 신생아기에 호흡기 증상으로 입원한 환아에서 RSV 감염비율은 $73.1 \%$ 로 높게 나타나 RSV가 신생아 호흡기 감염의 주원인이 되었음 을 확인할 수 있었다. 연령별 RSV 감염에 대한 하기도 호흡기 감염 비율을 연구한 보고에 따르면 역연령 0-3개월이 47.9\%, 4-6개월이 $37.0 \%, 7-11$ 개월이 $32.3 \%, 12-24$ 개월이 $25.1 \%$ 로 역 연령이 감소할 수록 급성 하기도 감염에서의 RSV 검출 비율이 증가한다고 나타닜 달. 만삭 신생아 중 30 일 미만에서 급성 하기도 호흡기 감염 증상이 있는 환자들을 대상으로 진행한 대구 지역에서의 국내연구에서는 RSV 검출률을 $63.8 \%$ 로 보고하였다 ${ }^{9)}$.

월별 분포에서 RSV 감염은 10 월부터 증가하기 시작하여 3월까지 확인되었고, 특히 1 월 전후에 가장 집중적으로 높게 나타났다. 이는 전국 다른 지역에서 보고된 자료들과 비교하였을 때 peak의 시기는 차이는 있으나 전반적으로 9-10월에서 이듬해 3월까지로 비슷하였 다 ${ }^{10-13)}$. RSV는 A와 B의 아형이 있고 매해 유행시기가 다르며, 본 연 구에서는 2012년과 2014년 기점으로 아형 변화가 있었고, 국내 같은 해에 이루어진 연구와 유행했던 아형이 일치하였다 ${ }^{14-17)}$. 국내 타지 역의 연도별 RSV 아형에 관한 자료 및 국내 질병관리본부에서의 조 사 $^{10,13,16,18)}$ 를 비교해 볼 때, 경기도 북부에 위치한 본 의료기관의 연 구와 국내 다른 지역 및 같은 연도 국내의 결과와 일치하였다. 기존 연구에 따르면 각 아형에 따라 중증도에 차이가 있다고 주장하는 연 구 $^{19-23)}$ 도 있고, 그렇지 않은 연구 ${ }^{24,25)}$ 도 있으나 본 연구에서는 아형 간의 유의한 차이는 없었다.

신생아나 미숙아에서의 RSV 호흡기 감염에 대한 임상 보고는 국 내외적으로 많지 않다. 국내에서는 Shin 등 ${ }^{26)}$ 이 기계환기요법이 필 요했던 생후 2 개월 미만의 영아들의 임상 양상을 연구하여 무호흡 이 중요한 증상임을 보고 하였고, Fodha 등 ${ }^{27}$ 은 28 일 미만의 신생아 는 다른 영아에 비해 입원 기간이 길고 중환자실에 입원하는 빈도 가 높다고 하였다. 72 명의 신생아의 임상 양상을 비교한 대구 지역 에서의 연구에서는 RSV 환자에서 호흡수 증가와 재원 기간의 증가 가 비 RSV 환자에 비하여 높은 것으로 보고하였다. 신생아집중치료 실에 급성 호흡기 감염으로 입원한 신생아 및 미숙아 46명을 대상으 로 한 국내의 연구 ${ }^{28)}$ 에서는 RSV군에서 호흡곤란으로 입원한 경우가 $34.8 \%$ 에 이르렀고 산소 투여가 필요한 경우나 수유 진행을 할 수 없 었던 경우가 각각 $52.5 \%$ 와 $43.5 \%$ 를 보여 non-RSV군에 비해 중증도 가 확연하게 높음을 보고하였다.

이번 연구에서는 RSV가 검출된 RSV군과 RSV를 제외한 다른 바이 러스가 검출된 non-RSV군, 바이러스가 검출되지 않은 Others군으 로 나누어 임상 양상을 비교하였다. Others군은 본 연구에서 시행한 검사 방법으로 검출되지 않은 다른 바이러스의 감염으로 간주할 수 도 있겠다. 혈액이나 호흡기 분비물에서 세균이 검출된 세균성 호흡 기 감염은 배제하였으나 세균 검출이 어려운 경우가 있고, 원인이 불
명확한 경우이므로 Others군으로 따로 분류하였다. 이 연구에서 사 용한 multiplex RT PCR 검사의 양성예측도 및 음성예측도는 전체 평 균 각각 94.7\%, 95.7\%였고, multiplex real time PCR 검사의 양성예 측도 및 음성예측도는 전체 평균 각각 $95.7 \%, 93.6 \%$ 로 보고되었다 ${ }^{29)}$. 이전 연구에서도 RT PCR 검사에서 바이러스가 분리되지 않은 경우가 $30 \%$ 정도로 보고되었으나, 호흡기 바이러스 감염으로 간주 하는 경우가 일반적이었다 ${ }^{28)}$. 그러나 이번 연구에서는 RSV군과 다 른 바이러스에 감염된 non-RSV군과의 임상 양상의 차이를 보다 명 확하게 분석하기 위해 RT PCR 검사에서 바이러스가 검출되지 않은 Others군을 non-RSV군에 포함시키지 않고, 세 군으로 나누었으며, $\mathrm{RSV}$ 군에는 다른 바이러스와 중복 감염된 경우를 제외하고 RSV만 검 출된 환아를 포함하였다. RSV 감염 환아에서 나타나는 흔한 임상 증 상은 기침, 흡기수포음, 흉곽함몰, 산소포화도 감소 순으로 확인되 었고 이런 호흡기 증상이 다른 바이러스에 인한 경우보다 유의하게 많았던 것으로 볼 때 RSV 감염에 의한 호흡기 증상의 중증도가 높음 을 확인하였다. $38^{\circ} \mathrm{C}$ 이상의 열은 Non-RSV군에서, C-반응단백의 증 가는 Others군에서 유의하게 높아 열과 C-반응단백의 증가는 RSV 군에서의 특징적인 소견이 아님을 확인하였다. RSV 감염 시 폐렴 과 기관지염을 시사하는 비정상 방사선 소견을 보이는 경우도 RSV 군에서 $65.0 \%$ 로 non-RSV군 $16.0 \%$ 에 비해 의미 있게 높았고, 산소 치료를 시행한 경우도 RSV군에서 $61.2 \%$ 로 가장 많았다. 기계환기 는 RSV군에서만 시행되는 등 좀 더 적극적인 치료를 요하는 경우가 많았고, 재원기간이 가장 길어 중증도가 확연히 높았음을 확인하였 다. RSV에 의한 호흡기 질환인 경우 임상 경과가 중할 수 있어 보다 집중적인 치료가 필요하겠다. 이번 연구의 대상 환아들을 보면 대부 분(92.9\%)이 37주 이상의 만삭 신생아였으며, 미숙아는 11 명(7.1\%) 포함되어 있었으나 평균 34주에서 36주 사이의 후기 미숙아였다. 본 대상 환아 중에서는 palivizumab을 접종받은 미숙아는 없었다. 32주 에서 36주에 태어난 후기 미숙아들은 만삭 신생아에 비해 호흡기 감 염에 취약하며 중증도가 증가하는 것으로 알려져 있지만 ${ }^{30)}$ 이번 연 구에서는 후기 미숙아의 수가 적어 만삭아와의 임상 양상을 비교할 수는 없었다.

후기 미숙아 및 만삭 신생아에서 RSV 감염 실태 및 합병증의 위험 성, 사회적 비용에 대하여는 미숙아에 비해 상대적으로 관심이 낮아 이에 대한 연구가 부족한 실정이다. 국내의 한 연구에서는 RSV에 대 한 급성 하기도 감염으로 입원하는 환자들은 대부분 만삭아이거나 기관지 폐이형성증과 같은 위험요인이 없는 palivizumab의 투여 대 상이 아닌 후기 미숙아들임을 보고하였고, 33-35주의 미숙아들이 접종 대상자에 포함되어 있는 스페인, 독일, 이탈리아 그리고 일본 처럼 이들을 예방접종 대상에 포함하는 연구가 필요함을 주장하였 다 $^{31)}$.

Palivizumab 접종은 현재 국내에서는 32주 미만의 미숙아이거 나 기관지폐이형성증과 같은 위험인자가 있는 경우와 형제가 있는 
36 주 미만이면서 한 명 이상의 손위 형제 혹은 손위 자매가 있는 경 우에 한해 이루어지고 있다. 그러나 이번 연구에서는 한 명 이상의 형제, 자매가 있는 경우는 오히려 non-RSV군에서 76.0\%로 RSV군 $43.7 \%$ 보다 의미 있게 높았다. 또한 RSV군에서 산후조리원에서 감 염된 경우가 $46.6 \%$ 로 non-RSV군 $24.0 \%$ 에 비하여 의미 있게 높음을 알 수 있었다. 손위 형제, 자매의 유무보다 산후조리원이 RSV군에서 더 의미 있는 위험인자로 볼 수 있겠다.

RSV는 비말로 전파되며, 바이러스로 오염된 물건이나 사람의 손 을 통해 전염될 수 있다. 잠복기는 바이러스 접촉 후 4-6일 정도이 나, 감염되자마자 혹은 하루 안에 감염자로부터 배출되기 시작하므 로, 증상이 나타난 이후 격리를 한다고 해도 이미 늦을 수 있다 ${ }^{32-34)}$. 특히 산후조리원처럼 감염에 취약한 신생아와 산모가 모여있는 곳 에서 RSV의 감염 가능성은 매우 높다고 볼 수 있다. 매년 겨울철만 되면 산후조리원에서 RSV의 집단 감염이 사회적 쟁점이 되고 있지 만, 핵가족화와 여성의 사회진출, 산후조리의 필요성에 대한 전통적 인 인식으로 인하여 1996년 처음 등장한 이래 30여 년 동안 600곳이 넘는 산후조리원이 생겨났고 출산 여성의 $60 \%$ 가량이 산후조리원을 이용하고 있다 ${ }^{35,36}$. 그러나 산후조리원에서 집단으로 발생한 신생아 를 대상으로 한 RSV 감염 연구는 부족하며, 경북지역에서 단일 산후 조리원에서 발생한 집단 감염에 대한 분석만 보고된바 있다 ${ }^{37)}$. 산후 조리원을 많이 이용하는 국내에서만 볼 수 있는 문화적 특성을 고려 하여 국내의 실정에 맞는 예방접종지침에 대한 연구가 필요하리라 생각된다. 이 연구에서는 만삭 신생아와 후기 미숙아에서, 산후조리 원에서 생활했던 환아가 새로운 고위험군이 될 가능성이 있는 것으 로 확인되었다. 따라서 RSV 유행시기인 가을부터 봄 사이 기간 동안 산후조리원 시설에 입실하게 되는 신생아에게까지 palivizumab의 예방접종 범위를 늘리는 방안을 고려할 필요성이 있어 보이며, 이에 대한 전국적인 대규모 연구가 필요하겠다.

본 연구에서는 신생아집중치료실에 입원한 신생아에서의 RSV 감 염에 대한 역학적, 인구학적, 임상적 특성 및 RSV 감염에 취약한 군 에 대하여 분석하고, palivizumab 예방접종 범위의 확대 필요성에 대하여 제언하였다. 그러나 이 연구에서의 대상자는 특정 지역 단일 병원의 후향적 연구라는 점에서 제한점이 있다.

그리고 연구 대상 환자가 지역 산부인과에서 출생한 만삭신생아 가 대부분을 차지하고 있으며, 미숙아의 비율이 높지 않은 2 차 의료 기관의 특성이 반영되었다. 또한, 대상 환자들은 의사의 주관에 의 하여 입원 결정을 하였으며 입원 환자만을 대상으로 하였기 때문에 외래에 방문한 증상이 경한 환아들의 임상 양상은 반영되지 않았다. 이러한 제한점에도 불구하고 그동안 주목받지 못했던 건강한 후기 미숙아 및 정상 신생아에서의 RSV 감염 양상에 대하여 분석했다는 점에서 그 의의가 있다. 또한 신생아를 대상으로 한 이전의 국내 연 구들과 비교하여, $26,28,37)$ 최근 5년간의 상대적으로 많은 환자 수를 대 상으로 임상 양상을 분석할 수 있었으며, 이전 보고가 주로 3 차 기관
에서의 연구인 것에 반해 이번 연구는 산후조리원이나 지역 의원에 서 일차적으로 전원 되는 2 차 의료기관에서의 분석으로 고위험군이 아닌 일반적인 신생아 인구에서의 양상을 분석할 수 있었다.

결론적으로 신생아기의 하기도 질환은 기존에 알려진 바와 같이 $\mathrm{RSV}$ 감염이 흔하고 입원 치료를 필요하게 하는 중요한 원인이며, 다 른 바이러스 감염에 비하여 임상 양상이 중하여 입원 기간이 길어질 수 있어 집중적인 치료와 주의를 요한다.

입원 환자의 대부분이 만삭아이거나 특별한 문제가 없는 후기 미 숙아인 경우로 현재 palivizumab의 대상요법이 아닌 환자들이었다. 특히 국내 특성상 조리원에 있는 경우에 위험요소가 될 수 있어 예 방에 대한 대책이 필요하며 국내 실정에 적합한 palivizumab에 대한 필요성에 대하여 향후 적극적이고 전향적인 다기관 연구가 필요하 다.

\section{REFERENCES}

1. Shay DK, Holman RC, Newman RD, Liu LL, Stout JW, Anderson LJ. Bronchiolitis-associated hospitalizations among US children, 1980-1996. JAMA 1999;282:1440-6.

2. Choi EH, Lee HJ, Kim SJ, Eun BW, Kim NH, Lee JA, et al. The association of newly identified respiratory viruses with lower respiratory tract infections in Korean children, 2000-2005. Clin Infect Dis 2006;43:585-92.

3. Meert K, Heidemann S, Abella B, Sarnaik A. Does prematurity alter the course of respiratory syncytial virus infection? Crit Care Med 1990;18:1357-9.

4. Resch B, Gusenleitner W, Muller W. The impact of respiratory syncytial virus infection: a prospective study in hospitalized infants younger than 2 years. Infection 2002;30:193-7.

5. Pedersen O, Herskind AM, Kamper J, Nielsen JP, Kristensen $\mathrm{K}$. Rehospitalization for respiratory syncytial virus infection in infants with extremely low gestational age or birthweight in Denmark. Acta Paediatr 2003;92:240-2.

6. Cardenas S, Auais A, Piedimonte G. Palivizumab in the prophylaxis of respiratory syncytial virus infection. Expert Rev Anti Infect Ther 2005;3:719-26.

7. Alan S, Erdeve O, Cakir U, Akduman H, Zenciroglu A, Akcakus $\mathrm{M}$, et al. Outcome of the respiratory syncytial virus related acute lower respiratory tract infection among hospitalized newborns: a prospective multicenter study. J Matern Fetal Neonatal Med 2016;29:2186-93.

8. Hall CB, Weinberg GA, Blumkin AK, Edwards KM, Staat MA, Schultz AF, et al. Respiratory syncytial virus-associated hospitalizations among children less than 24 months of age. Pediatrics 2013;132:e341-8.

9. Song WS, Song BJ, Kim WD. Clinical characteristics of acute 
respiratory tract infections in full-term newborns without risk factors. Neonatal Med 2015;22:27-33.

10. Yoon GH, Kim YH. The clinical characteristics in infantile bronchiolitis and pneumonia according to respiratory syncytial virus subgroups: experience of single tertiary medical center from 2010 to 2012. Allergy Asthma Respir Dis 2013;1:84-9.

11. Seo JJ, Kim MJ, Kim SH, Kee HY, Chung JK, Kim ES, et al. Characterization of respiratory viral infection in children in Gwangju. Infect Chemother 2008;40:218-29.

12. Kim HY, Kim KM, Kim SH, Son SK, Park HJ. Clinical manifestations of respiratory viruses in hospitalized children with acute viral lower respiratory tract infections from 2010 to 2011 in Busan and Gyeongsangnam-do, Korea. Pediatr Allergy Respir Dis 2012;22:265-72.

13. Park KH, Shin JH, Lee EH, Seo WH, Kim YK, Song DJ, et al. Seasonal variations of respiratory syncytial virus infection among the children under 60 months of age with lower respiratory tract infections in the capital area, the Republic of Korea, 2008-2011. J Korean Soc Neonatol 2012;19:195-203.

14. Jung HD, Cheong HM. Prevalence of respiratory viruses in patients causing acute respiratory infections, 2013. Public Health Wkly Rep 2014;7:805-12.

15. Hwang SJ, Park DJ, Gu PT, Koo HS, Lee MO. Characteristics of respiratory syncytial virus isolated from acute respiratory infectious disease in Busan. J Bacteriol Virol 2016;46:173-80.

16. Jung HD, Cheong HM, Kim SS. Prevalence of respiratory viruses in patients with acute respiratory infections, 2014. Public Health Wkly Rep 2016;9:26-36.

17. Yoon GH, Kim YH. The clinical characteristics in infantile bronchiolitis and pneumonia according to respiratory syncytial virus subgroups: experience of single tertiary medical center from 2010 to 2012. Allergy Asthma Respir Dis 2013;1:84-9.

18. Kang SY, Hong CR, Kang HM, Cho EY, Lee HJ, Choi EH, et al. Clinical and epidemiological characteristics of human metapneumovirus infections, in comparison with respiratory syncytial virus A and B. Korean J Pediatr Infect Dis 2013;20:168-77.

19. McConnochie KM, Hall CB, Walsh EE, Roghmann KJ. Variation in severity of respiratory syncytial virus infections with subtype. J Pediatr 1990;117(1 Pt 1):52-62.

20. Martinello RA, Chen MD, Weibel C, Kahn JS. Correlation between respiratory syncytial virus genotype and severity of illness. J Infect Dis 2002;186:839-42.

21. Gilca R, De Serres G, Tremblay M, Vachon ML, Leblanc E, Bergeron MG, et al. Distribution and clinical impact of human respiratory syncytial virus genotypes in hospitalized children over 2 winter seasons. J Infect Dis 2006;193:54-8.

22. Hendry RM, Burns JC, Walsh EE, Graham BS, Wright PF, Hemming VG, et al. Strain-specific serum antibody responses in infants undergoing primary infection with respiratory syncytial virus. J Infect Dis 1988;157:640-7.

23. Taylor CE, Morrow S, Scott M, Young B, Toms GL. Comparative virulence of respiratory syncytial virus subgroups A and B. Lancet 1989;1:777-8.

24. Hall CB, Walsh EE, Schnabel KC, Long CE, McConnochie KM, Hildreth SW, et al. Occurrence of groups A and B of respiratory syncytial virus over 15 years: associated epidemiologic and clinical characteristics in hospitalized and ambulatory children. J Infect Dis 1990;162:1283-90.

25. Devincenzo JP. Natural infection of infants with respiratory syncytial virus subgroups A and B: a study of frequency, disease severity, and viral load. Pediatr Res 2004;56:914-7.

26. Shin SH, Kim JR, Lee JA, Choi CW, Kim EK, Choi EH, et al. Clinical characteristics of severe respiratory syncytial virus infection requiring mechanical ventilation in neonatal period and early infancy. Korean J Pediatr 2008;51:372-6.

27. Fodha I, Vabret A, Ghedira L, Seboui H, Chouchane S, Dewar J, et al. Respiratory syncytial virus infections in hospitalized infants: association between viral load, virus subgroup, and disease severity. J Med Virol 2007;79:1951-8.

28. Park SH, Cho HJ, Shim SY, Son DW, Eun BW, Sun YH, et al. Acute respiratory infections in the neonatal intensive care unit: isolation of viruses and the characteristics of respiratory syncytial virus infection. J Korean Soc Neonatol 2009;16:182-9.

29. Jung YJ, Kwon HJ, Huh HJ, Ki CS, Lee NY, Kim JW. Comparison of the AdvanSure real-time RT-PCR and Seeplex RV12 ACE assay for the detection of respiratory viruses. J Virol Methods 2015;224:42-6.

30. Olabarrieta I, Gonzalez-Carrasco E, Calvo C, Pozo F, Casas I, Garcia-Garcia ML. Hospital admission due to respiratory viral infections in moderate preterm, late preterm and term infants during their first year of life. Allergol Immunopathol (Madr) 2015;43:469-73.

31. Min SJ, Song JS, Choi JH, Seon HS, Kang EK, Kim DH, et al. Analysis of palivizumab prophylaxis in patients with acute lower respiratory tract infection caused by respiratory syncytial virus. Korean J Pediatr Infect Dis 2011;18:154-62.

32. Hall CB. Nosocomial respiratory syncytial virus infections: the "Cold War" has not ended. Clin Infect Dis 2000;31:590-6.

33. Garcia CG, Bhore R, Soriano-Fallas A, Trost M, Chason R, Ramilo O, et al. Risk factors in children hospitalized with RSV bronchiolitis versus non-RSV bronchiolitis. Pediatrics 2010; 126:e1453-60.

34. Hall CB, Douglas RG Jr, Geiman JM. Respiratory syncytial virus infections in infants: quantitation and duration of shedding. J Pediatr 1976;89:11-5.

35. Ministry of Health and Welfare. Status of postpartum care centers nationwide [Internet]. Sejong: Ministry of Health and Welfare; 2016 [cited 2018 Oct 8]. Available from: http://www.mohw. 
go.kr/react/gm/sgm0601vw.jsp?PAR_MENU_ID=13\&MENU_ ID $=1304020701$ \&page $=3 \&$ CONT_SEQ=338140.

36. Lee SS, Park JS, Lee SY, Oh MA, Choi HJ, Song MY. The 2015 national survey on fertility and family health and welfare.
Sejong: Korea Institute for Health and Social Affairs, 2015.

37. Hong SJ, Kim DK, Lee DS, Cho SM, Choi SM. RSV outbreak at a single postpartum care center in Gyeongsangbukdo. Korean J Perinatol 2016;27:60-6. 